\title{
The search for new 4-amino-5-methyl-4H-1,2,4-triasole-3-thion derivatives with diuretic activity
}

\section{T. V. Kravchenko}

Zaporizhzhia State Medical University, Ukraine

1,2,4-Triazole derivatives have been widely used in medical practice due to their wide spectrum of biological activities and low toxicity, as they have 1,2,4-triazole cycle in their structure. That makes 1,2,4-triazole derivatives a very promising and attractive class of organic compounds in research of their physical and chemical properties, and biological activity determining. In order to find new substances with potential biological activity 20 new compounds of 4-amino-5-methyl-4H-1,2,4-tiazole-3-thion derivatives were synthesized, which have never been described in literature before.

The objective of this study was the research of bioactivity of 4-amino-5-methyl-4H-1,2,4-tiazole-3-thion derivatives.

Materials and methods. Compounds of research were synthesized in Department of Toxicological and Inorganic Chemistry of ZSMU. Berchin method was used in order to estimate the effect of compounds on excretory function of kidneys.

Results. Diuretic activities of 4-amino-5-methyl-4H-1,2,4-tiazole-3-thion derivatives were studied. The compounds exhibit both diuretic and antidiuretic effects. It is worth noting that 4-((R-idene)amino)-5-methyl-4H-1,2,4-triazole-3-thion derivatives demonstrated both moderate and high diuretic activity. In such way, introduction of 3,4-methoxybenzyl, 3,5-methoxybenzyl and 2-chloro-6-fluorobenzyl substituents into the structure of 4-((R-idene)amino)-5-methyl-4H-1,2,4-triazole-3-thion slightly increased diuretic effect. Reduction of compounds 4-((4-bromobenzylidene)amino)-5-methyl-4H-1,2,4-triazole-3-thion, 5-methyl-4-((thiophen-2-ylmethylene)amino)-4H-1,2,4-triazole-3-thion, 4-((2-chloro-6-fluorobenzylidene)amino)-5-methyl-4H-1,2,4-triazole-3-thion caused decline of diuretic activity. The most potent bioactivity was observed in 4-((4-methoxybenzyl)amino)-5-methyl-4H-1,2,4-triazole3-thion.

Conclusion. Derivatives of 4-amino-5-methyl-4H-1,2,4-tiazole-3-thion exhibit both diuretic and antidiuretic effects. "Structure - effect" relation was shown. The most potent activity was observed in 4-((4-methoxybenzyl)amino)-5-methyl-4H-1,2,4-triazole-3-thion.

\section{Пошук нових діуретичних речовин серед похідних 4-аміно-5-метил-4H-1,2,4-тріазол- 3-тіону}

\section{Т. В. Кравченко}

Похідні 1,2,4-тріазолу широко застосовують у медичній практиці завдяки великому спектру біологічної дії та низькій токсичності, що зумовлено наявністю в їхній структурі тріазольного циклу. Цей фракт робить особливо перспективним і цікавим дослідження фізико-хімічних і біологічних властивостей цього класу органічних сполук. Для пошуку нових потенційно біологічно активних речовин синтезували 20 нових сполук, які раніше не описані у фаховій літературі, - похідні 4-аміно5-метил-4Н-1,2,4-тріазол-3-тіонів.

Мета роботи - дослідження діуретичної активності похідних 4-аміно-5-метил-4H-1,2,4-тріазол-3-тіонів.

Матеріали та методи. Сполуки синтезували на кафедрі токсикологічної та неорганічної хімії ЗДМУ. Для встановлення впливу сполук на екскреторну функцію нирок використовували метод Є. Б. Берхіна.

Результати. Дослідили діуретичну активність похідних 4-аміно-5-метил-4H-1,2,4-тріазол-3-тіонів. Вони проявляють як діуретичний, так антидіуретичний ефект. Досліджуючи діуретичну дію 4-((R-іден)аміно)-5-метил-4H-1,2,4-тріазол-3-тіонів, слід відзначити, що вони виявляють помірний і високий діуретичний ефект. Так, введення в молекулу 4-((R-іден)аміно)-5метил-4H-1,2,4-тріазол-3-тіону 3,4-метоксибензилового, 3,5-метоксибензилового та 2-хлор-6-фрторбензилового радикалу призводить до незначного посилення діуретичного ефекту. Відновлення сполук II, III, IX призводить до послаблення діуретичної дії. Найбільш активним є 4-((4-метоксибензил)аміно)-5-метил-4Н-1,2,4-тріазол-3-тіон.

Висновки. Похідні 4-аміно-5-метил-4Н-1,2,4-тріазол-3-тіонів проявляють як діуретичний, так і антидіуретичний ефект. Встановили взаємозв'язок «структура - дія». Найбільш активною сполукою є 4-((4-метоксибензил)аміно)-5-метил-4Н1,2,4-тріазол-3-тіон.
Key words: 1,2,4-triazole, diuretic effect, derivatives of 4-amino-5methyl-4H-1,2,4triazole-3-thion.

\section{Zaporozhye} medical journal 2018; 20 (3), 421-424 DOI: 10.14739/2310-1210 2018.3.130548

\section{E-mail:} tk8724210@gmail.com
Кнючові слова: 1,2,4-тріазол, Аіуретичний ефект, похіані 4-аміно-5метил-4H-1,2,4тріазол-3-тіонів.

Запорізький медичний журнал. - 2018. T. 20, № 3(108). -

C. 421-424

\section{Поиск новых диуретических веществ среди производных 4-амино-5-метия-4H-1,2,4- триазол-3-тиона}

\section{Т. В. Кравченко}

Производные 1,2,4-триазола получили широкое применение в медицинской практике благодаря значительному спектру биологического действия и низкой токсичности, что обусловлено наличием в их структуре триазольного цикла. Этот факт делает особенно перспективным и интересным исследование физико-химических и биологических свойств данного класса органических соединений. Для поиска новых потенциально биологически активных веществ синтезировали 20 новых соединений, ранее неописанных в специализированной литературе, - производные 4-амино-5-метил-4Н-1,2,4-триазол-3-тионов.

Цель работы - исследование диуретической активности производных 4-амино-5-метил-4Н-1,2,4-триазол-3-тионов.
Ключевые слова: 1,2,4-триазол, Аиуретический эффект, производные 4-амино-5-метил-4H-1,2,4триазол-З-тионов.

C. 421-424 
Материалы и методы. Исследуемые соединения были синтезированы на кафедре токсикологической и неорганической химии ЗГМУ. Для установления влияния соединений на экскреторную функцию почек использовали метод Е. Б. Берхина.

Результаты. Исследована диуретическая активность производных 4-амино-5-метил-4H-1,2,4-триазол-3-тионов. Они проявляют как диуретический, так антидиуретический эфффекты. При исследовании диуретического действия 4-((R-иден) амино)-5-метил-4Н-1,2,4-триазол-3-тионов следует отметить, что они проявляют умеренный и высокий диуретический эффект. Введение в молекулу 4-((R-иден)амино)-5-метил-4H-1,2,4-триазол-3-тиона 3,4-метоксибензилового, 3,5-метоксибензилового и 2-хлор-6-фторбензилового радикала приводит к незначительному усилению диуретического эффекта. Восстановление соединений II, III, IX приводит к снижению диуретического действия. Наиболее активным является 4-((4-метоксибензил)амино)-5-метил-4Н-1,2,4-триазол-3-тион.

Выводы. Производные 4-амино-5-метил-4Н-1,2,4-триазол-3-тионов проявляют как диуретический, так и антидиуретический эффект. Установлена взаимосвязь «структура - действие». Наиболее активным соединением является 4-((4-метоксибензил)амино)-5-метил-4H-1,2,4-триазол-3-тион.

\section{Introduction}

1,2,4-triazoles are one of the novel and promising substances among high variety of organic heterocyclic compounds, which show wide range of biological activities and have low toxicity. In literature, scientists have been paying attention in their researches on diuretic activity of thioderivatives of 1,2,4-triazole. Considering results of the studies, further researches in this field may hold promise to obtain such substances [1-7].

It is known that therapeutic and clinical effects of diuretic agents are related not only to increasing of diuresis. Diuretics are often being prescribed also to treat arterial hypertension and cardiovascular, liver and kidney diseases, which are followed by edema [8-16].

Table 1. The structure of 4-((R-idene)-amino)-5-methyl-4H-1,2,4-triazole-3-thions<smiles>[R]C=Nn1c(C)n[nH]c1=S</smiles>

\begin{tabular}{l|l|ll} 
Substance № & $\mathbf{R}$ & Substance № & $\mathbf{R}$ \\
\hline I & $3,5-\left(\mathrm{OCH}_{3}\right)_{2}-\mathrm{C}_{6} \mathrm{H}_{3}$ & II & $4-\mathrm{BrC}_{6} \mathrm{H}_{4}$ \\
III & $2-\mathrm{S}-\mathrm{C}_{4} \mathrm{H}_{3}$ & IV & $4-\left(\mathrm{OCH}_{3}\right)_{6} \mathrm{H}_{4}{ }^{*}$ \\
V & $3-\mathrm{FC}_{6} \mathrm{H}_{4}$ & VI & $3,4-\left(\mathrm{OCH}_{3}\right)_{6} \mathrm{C}_{6} \mathrm{H}_{3}{ }^{*}$ \\
VII & $3-\mathrm{Br}-4-\mathrm{C}_{6} \mathrm{H}_{3}$ & VIII & $2,3-\left(\mathrm{OCH}_{3}\right)_{2} \mathrm{C}_{6} \mathrm{H}_{3}$ \\
IX & $2-\mathrm{Cl}-6-\mathrm{FC}_{6} \mathrm{H}_{3}$ & X & $4-\mathrm{FC}_{6} \mathrm{H}_{4}$ \\
\hline
\end{tabular}

*: compounds (IV, VI) [17] were studied in other researches before, but their diuretic activities were not investigated; thus, our study has evaluated diuretic activities of the substances for the first time.

Table 2. The structure of 4-((R)-amino)-5-methyl-4H-1,2,4-triazole-3-thions<smiles>[R]CNn1c(C)n[nH]c1=S</smiles>

\begin{tabular}{|c|c|c|c|}
\hline Substance № & $\mathbf{R}$ & Substance № & $\mathbf{R}$ \\
\hline $\mathrm{XI}$ & $3,5-\left(\mathrm{OCH}_{3}\right)_{2}-\mathrm{C}_{6} \mathrm{H}_{3}$ & XII & 4- $-\mathrm{BrC}_{6} \mathrm{H}_{4}$ \\
\hline XIII & $2-\mathrm{S}-\mathrm{C}_{4} \mathrm{H}_{3}$ & XIV & 4- $\left(\mathrm{OCH}_{3}\right) \mathrm{C}_{6} \mathrm{H}_{4}$ \\
\hline$x V$ & $3-\mathrm{FC}_{6} \mathrm{H}_{4}$ & $X V I$ & $3,4-\left(\mathrm{OCH}_{3}\right)_{2} \mathrm{C}_{6} \mathrm{H}_{3}$ \\
\hline XVII & 3-Br-4F- $\mathrm{C}_{6} \mathrm{H}_{3}$ & XVIII & 2,3-( $\left(\mathrm{OCH}_{3}\right)_{2} \mathrm{C}_{6} \mathrm{H}_{3}$ \\
\hline XIX & 2-Cl-6- $\mathrm{FC}_{6} \mathrm{H}_{3}$ & $x X$ & $4-\mathrm{FC}_{6} \mathrm{H}_{4}$ \\
\hline
\end{tabular}

Diuretic activity of studied new substances may be highly valuable for medical treatment of various severe conditions of the body. This had determined objective of the study, which was conducted to estimate effects of 4-amino-5-methyl-4H-1,2,4-tiazole-3-thion derivatives on excretory function of kidneys.

\section{The aim}

The aim of work was to study diuretic activities of 4-amino5-methyl-4H-1,2,4-tiazole-3-thion derivatives.

\section{Materials and methods}

Compounds for research were synthesized at the Department of Toxicological and Inorganic Chemistry of ZSMU.

Berchin [17] method was used in order to estimate the effect of compounds on excretory function of kidneys. 7 Rats were used in each series of experiment, which were continuously held on a diet and had free access to water. Before the experiment animals were deprived from food and water for 2 hours. Then, gastric tube was used to introduce dose of $1 / 10 L D_{50}$ of the substances in water suspension stabilized in Tween-80 into animals' stomach. 30 minutes later drinking water was introduced with loading of $5 \mathrm{ml}$ per $100 \mathrm{~g}$ of body mass. Urine was collected in 2 and 4 hours.

\section{Results and discussion}

Statistical analysis of the obtained results was conducted using parametric statistics (Student's t-test). Substances "Hypothiazid" by Sanofi-Aventis Ukraine ${ }^{\circledR}$, "Furosemide" by Darnytsia ${ }^{\circledR}$ were used for comparison.

Studies of diuretic activities among 1,2,4-triazole derivatives were reviewed. The studies of our state's scientists approve that 4-R-5-R1-1,2,4-triazol-3-thione derivatives demonstrate diuretic activities [18,19].

Researchers have also obtained patents of Ukraine for 3-((2-chloroethlyl)thio)-4-ethyl-5-(phenoxymethyl)-4H1,2,4-triazole and 4-ethyl-3-(phenoxymethyl)-5-((2-((5-( phenoxymethyl)-4-phenyl-4H-1,2,4-triazol-3-yl)thio)-ethyl) thio)-4H-1,2,4-triazole [20].

Therefore, the objects of this research of diuretic activities were new 4-amino-5-methyl-4H-1,2,4-triazol-3-thiones.

Diuretic activities of 4-amino-5-methyl-4H-1,2,4-tiazole-3-thion derivatives were studied. It is worth noting that 4-((R-idene)amino)-5-methyl-4H-1,2,4-triazole-3-thion derivatives demonstrated both moderate and high diuretic activity. In such way, introduction of 3,4-dimethoxyben- 
Table 3. Diuretic activities of 4-amino-5-methyl-4H-1,2,4-tiazole-3-thions derivatives

\begin{tabular}{|c|c|c|c|c|}
\hline Substance № & $120 \mathrm{~min}, \mathrm{M} \pm \mathrm{m}, \mathrm{mL}$ & $\Delta \%$ of the reference & $240 \mathrm{~min}, M \pm m, \mathrm{~mL}$ & $\Delta \%$ of the reference \\
\hline Reference & $1.390 \pm 0.103$ & - & $2.110 \pm 0.122$ & - \\
\hline Furosemide & $3.890 \pm 0.296$ & 180.41 & $6.030 \pm 0.113$ & 185.14 \\
\hline Hypothiazid & $2.530 \pm 0.280$ & 82.47 & $3.590 \pm 0.215$ & 69.59 \\
\hline I & $1.560 \pm 0.078^{*}$ & 12.37 & $3.360 \pm 0.194$ & 58.78 \\
\hline ॥ & $2.230 \pm 0.228$ & 60.82 & $4.6700 \pm 0.0306$ & 120.95 \\
\hline III & $1.700 \pm 0.271^{*}$ & 22.68 & $4.2400 \pm 0.0461^{*}$ & 100.68 \\
\hline IV & $2.010 \pm 0.132$ & 45.36 & $4.000 \pm 0.600$ & 89.19 \\
\hline V & $2.040 \pm 0.232$ & 47.42 & $4.010 \pm 0.322$ & 89.86 \\
\hline VI & $1.790 \pm 0.233^{*}$ & 28.87 & $3.210 \pm 0.438$ & 52.03 \\
\hline Reference & $1.610 \pm 0.180$ & - & $2.43 \pm 0.113$ & - \\
\hline VII & $3.060 \pm 0.333$ & 90.05 & $6.13 \pm 0.436$ & 152.35 \\
\hline VIII & $3.010 \pm 0.280$ & 87.38 & $5.770 \pm 0.458^{*}$ & 137.65 \\
\hline IX & $1.760 \pm 0.134$ & 9.23 & $3.960 \pm 0.226$ & 62.94 \\
\hline $\mathrm{x}$ & $2.430 \pm 0.248$ & 50.97 & $4.560 \pm 0.348$ & 87.65 \\
\hline$X I$ & $2.700 \pm 0.395$ & 67.85 & $4.010 \pm 0.261$ & 65.29 \\
\hline XII & $1.400 \pm 0.208^{*}$ & -12.97 & $2.300 \pm 0.375^{\star}$ & -5.29 \\
\hline XIII & $1.530 \pm 0.115$ & -4.98 & $2.270 \pm 0.087$ & -6.47 \\
\hline Reference & $1.360 \pm 0.107$ & - & $2.310 \pm 0.130$ & - \\
\hline XIV & $1.870 \pm 0.148$ & 37.89 & $5.940 \pm 0.352$ & 157.73 \\
\hline$X V$ & $1.570 \pm 0.117$ & 15.79 & $2.990 \pm 0.254$ & 29.48 \\
\hline $\mathrm{XVI}$ & $1.590 \pm 0.179^{\star}$ & 16.84 & $2.910 \pm 0.192$ & 26.38 \\
\hline XVII & $2.430 \pm 0.586$ & 78.95 & $4.810 \pm 0.486$ & 108.78 \\
\hline XVIII & $1.710 \pm 0.135$ & 26.32 & $3.260 \pm 0.221$ & 41.25 \\
\hline XIX & $1.090 \pm 0.202^{*}$ & -20.00 & $2.070 \pm 0.191^{*}$ & -10.17 \\
\hline Reference & $1.310 \pm 0.059$ & - & $2.350 \pm 0.256$ & - \\
\hline$X X$ & $1.970 \pm 0.224^{*}$ & 50.00 & $4.290 \pm 0.264$ & 82.38 \\
\hline
\end{tabular}

$*: P<0.05$ in relation to the reference.

zyl, 3,5-dimethoxybenzyl and 2-chloro-6-fluorobenzyl radicals into the structure of 4 -((R-idene)amino)-5-methyl-4H-1,2,4-triazole-3-thion slightly increased the diuretic effect. Compounds 4-((4-fluorobenzylidene) amino)-5-methyl-4H-1,2,4-triazole-3-thion, 4-((3-fluorobenzylidene)amino)-5-methyl-4H-1,2,4-triazole-3-thion and 4-((4-methoxybenzylidene)amino)-5-methyl-4H-1,2,4triazole-3-thion showed more potent activity, then substance hypothiazide used for comparison.

It is worth mentioning that introduction of thiophene-2-ylmethyl, 2,3-dimethoxybenzyl and 4-bromobenzyl radicals into the structure of 4-((R-idene)amino)-5-methyl-4H-1,2,4triazole-3-thion increased its diuretic effect as well. The highest bioactivity among 4-((R-benzylidene)amino)-5methyl-4H-1,2,4-triazole-3-thion derivatives was observed for 4-((3-bromo-4-fluorobenzylidene)amino)-5-methyl-4H1,2,4-triazole-3-thion.

Reduction of compounds II, III, IX caused decline of diuretic activity (substances XII, XIII, XIX).

Substitution of thiophene-2-ylmethyl radical by 3-fluorobenzyl, 3,4-dimethoxybenzyl, 2,3-dimethoxybenzyl radicals in the structure of 4-((R)amino)-5-methyl-4H-1,2,4-triazole3-thion slightly increased the diuretic effect.

Reduction of compound VII led to decline of diuretic effect (substance XVII). Reduction of compound IV caused significant enhancement of diuretic activity.

\section{Conclusions}

1. Diuretic activities of 4-amino-5-methyl-4H-1,2,4-triasole-3-thion derivatives were studied using Berchin method.

2. Derivatives of 4-amino-5-methyl-4H-1,2,4-triasole3-thion demonstrate both diuretic and antidiuretic effects.

3. "Structure - effect" relation was shown.

4. The most potent activity was observed for 4-((4-methoxybenzyl)amino)-5-methyl-4H-1,2,4-triazole-3-thion.

Conflicts of Interest: author has no conflict of interest to declare. Конфлікт інтересів: віАсутній.

Information about author:

Kravchenko T. V., Assistant of the Department of Organization and Economics of Pharmacy, Medical and Pharmaceutical Law, Zaporizhzhia State Medical University,Ukraine.

Відомості про автора:

Кравченко Т. В., асистент каф. управління і економіки фармації, медичного та фармацевтичного правознавства, Запорізький Аержавний медичний університет, Україна.

Сведения об авторе:

Кравченко Т. В., ассистент каф. управления и экономики фармации, медицинского и фармацевтического правоведения, Запорожский государственный меАицинский университет, Украина. 
НаАійшла Ао реАакції / Received: 20.01.2018

Після Аоопрацювання / Revised: 19.02.2018

Прийнято Ао Аруку / Accepted: 01.03.2018

\section{References}

[1] Pruglo, Ye. S. (2015) Diuretychna aktyvnist 3-(5-bromfuran-2-il)-4 R-(4N)-1,2,4-triazol-5-tioniv, yikh S-pokhidnykh ta 2-(5-bromfuran2-il)-5-R'-tiazolo[3,2-b][1,2,4]triazol-6(5N)-oniv [Diuretic activity of 3-(5-bromfuran-2-yl)-4-R-(4h)-1,2,4-triazole-5-thione, their S-derivatives and 2-(5-bromfuran-2-yl)-5-r'-thiazolo[3,2-b][1,2,4]triazole6(5h)-ones]. Current issues in pharmacy and medicine: science and practice, 3, 9-13. [in Ukrainian]. doi: http://dx.doi.org/10.14739/24092932.2015.3.52274

[2] Kucheryavyi, Yu. M., Kaplaushenko, A. G., \& Pruhlo, Ye. S. (2014) Synthesis and diuretic activity of 2-(5-(phenoxymethyl)-4-r1-1,2,4-triazole-3-ylthio)acetic acids and their salts. Zaporozhye medical journal, 6(87), 101-104. doi: https://doi.org/10.14739/2310-1210.2014.6.35871.

[3] Danilchenko, D. M. \& Safonov, A. A. (2017) Diuretic activity of 2-((4-amino-5-R-4H-1,2,4-triazole-3-yl)thio)acetohydrazides. Zaporozhye medical journal 19, 4(103), 517-519. doi: 10.14739/2310-1210.2017.4.105283.

[4] Britanova, T. S., Pruglo, Ye. S., Hotsulya, A. S., Panasenko, A. I., \& Knysh, Ye. G. (2013) Vyvchennia diuretychnoi aktyvnosti ilidenpokhidnyh halohenidiv 3,5-R-4H-amino-R1-1,2,4-triazolu [Study of the diuretic activity ylidenderivatives halogenides of 3,5-R-4-amino-1,2,4-triazole]. Current issues in pharmacy and medicine: science and practice, 1(11) 18-20. [in Ukrainian]

[5] Shcherbyna, R. O., Panasenko, A. I., Knysh, Ye. H., Bilai, I. M. Pruglo, Ye. S., \& Mikhailiuk, Ye. O. (2011) Vplyv pokhidnykh 4-R-5 R1-1,2,4-trizol-3-tionu na vydilnu funktsiiu nyrok [Effect of 4-R-5-R11,2,4-trizole-3-thione derivatives on excretory function of kidneys]. Liky - liudyny. Proceedings of the XXVIII All-Ukrainian Scientific and Practical Conference with International Participation, (P. 15-16). Kharkiv. [in Ukrainian].

[6] Parchenko, V. V. (2014) Syntez, peretvorennia, fizyko-khimichni ta biolohichni vlastyvosti v riadi 5-furylzamishchenykh 1,2,4-triazol-3tioniv (Dis... dokt. farm. nauk). [Synthesis, transformation, physical, chemical and biological properties in the row of 1,2,4-triazol-3-thione 5 -furyl-derivatives. Dr. farm. sci. diss.]. Zaporizhzhia. [in Ukrainian].

[7] Panasenko, O. I. (2005) Syntez, peretvorennia, fizyko-khimichni ta biolohichni vlastyvosti amino- $i$ tiopokhidnykh 1,2,4-triazolu (Dis.. dokt. farm. nauk). [Synthesis, transformation, physical, chemical and biological properties of amino- and thio-derivatives of 1,2,4-triazoles. Dr. farm. sci. diss.]. Kyiv. [in Ukrainian].

[8] Safonov, A. A. (2014) Syntez, fizyko-khimichni ta biolohichni vlastyvosti pokhidnykh 5-geteryl-4-R-amino-1,2,4-triazol-3-tioliv (Dis... kand. farm. nauk). [Synthesis, physical, chemical and biological properties of 5-geteryl-4-R-amino-1,2,4-triazole-3-thiol derivatives. Dr. farm. sci. diss]. Zaporizhzhia. [in Ukrainian].

[9] Ermakova, X. G., Shaulina, L. P., Kuznetsova, N. P., et al. (2012) Sorption Recovery of Noble Metal lons with a Copolymer of I-Vinyl-I,2,4-triazole with Acrylonitrile. Rus. J. of Applied Chem . 85(8), 1289-1295.

[10] Salionov, V. O. (2016) Syntez, fizyko-khimichni ta biolohichni vlastyvosti pokhidnykh 5-tiienil-4-(alkil-, aril)-1,2,4-triazol-3-tioniv (Dis... kand. farm. nauk). [Synthesis, physical, chemical and biological properties of 5-thienyl-4-(alkyl-, aryl)-1,2,4-triazole-3-thione derivatives. Dr. farm. sci. diss]. Zaporizhzhia. [in Ukrainian]

[11] Shcherbyna, R. O., Panasenko, O. I., \& Knysh, Ye. H. (2016) Vyvchennia antyoksydantnoi aktyvnosti solei 2-((4-R-3-(morfolinometylen)-4H-1,2,4triazol-5-il)tio)atsetatnykh kyslot [The studying of antioxidant activity of salts 2-((4-r-3-(morpholinomethylen)-4h-1,2,4-triazole-5-yl)thio)acetic acids]. Ukrainskyi biofarmatsevtychnyi zhurnal, 1, 37-40. [in Ukrainian]

[12] Yanchenko, V. O. (2005) Syntez ta vlastyvosti pokhidnykh 4-amino-3-merkapto-4N-1,2,4-tryazolu (Dis... kand. farm. nauk). [Synthesis and properties of 4-amino-3-mercapto-4H-1,2,4-triazole derivatives. Dr. farm. sci. diss]. Kharkiv. [in Ukrainian]

[13] Kaplaushenko, A. G. (2015) Khimichni vlastyvosti amino- i tiozamishchenykh 1,2,4-triazoliv [Chemical properties of amino- and thio-derivatives of 1,2,4-triazoles]. Current issues in pharmacy and medicine: science and practice, 1(17), 101-106. [in Ukrainian]. doi: https://doi. org/10.14739/2409-2932.2015.1.41702.

[14] Fizer, M. M. (2016) Syntez kondensovanykh azaheterotsykliv na osnovi pokhidnykh 5-amino-1,2,4-tryazol-3-tionu (Dis...kand. khim. nauk). [Synthesis of condensed azaheterocyclic compounds based on 5-amino-1,2,4-triazole-3-thione derivatives. Dr. chem. sci. diss.] Uzhhorod. [in Ukrainian].

[15] Gotsulya, A. S., Kamyshnyi, O. M., Polishchuk, N. M., Panasenko, O. I. \& Knysh, Ye. G. (2015). Research of the antimicrobial and antifungal activity of 7-((3-thio-4-R-4H-1,2,4-triazoles-3-yl)methyl)theophylline S-derivatives. Zaporozhye medical journal, 4(91), 95-99. [in Russian]. doi: http://dx.doi.org/10.14739/2310-1210.2015.4.50302.
[16] Barmin, M. I., \& Mel'nykov, V. V. (2002) Novye amino-1,2,4-triazolit $i$ tetrazolil alkany [New 1,2,4-triazolyl and tetrazolyl alkanes]. Saint Petersburg [in Russian].

[17] Berkhin, E. B. (1977) Metody izucheniya dejstviya novykh khimicheskikh soedinenij na funkciyu pochek [Approaches to determine effects of chemical compounds on kidney functions]. Khimiko-farmacevticheskij zhurnal, 11(5), 3-11. [in Russian].

[18] Pruglo, Ye. S., Bilai, I. M., Scherbyna, R. O., et al. (2010) Vplyv S-pokhidnyk 4-R-5-R1-1,2,4-triazol-3-tionu na vydilnu funktsiiu nyrok pry eksperymentalnii hiperlipidemii [Effect of S-derivatives of 4-R-5R1-1,2,4-triazol-3-thione on excretory function of kidneys during the experimental hyperlipidemia]. Farmatsevtychnyi zhurnal, 6, 62-67. [in Ukrainian].

[19] Kucheriavyi, Yu. M., Kaplaushenko, A. H., \& Pruglo, Ye. S (patentee) (2015) Patent 98923 Ukraina, C07D 249/00 A61K 31/41. 3-((2-hloretil) tio)-4-etyl-5-(fenoksymetyl)-4H-1,2,4-triazol, scho vyiavliaie diuretychnu aktyvnist [Patent of Ukraine №98923. C07D 249/00 A61K 31/41. The 3-((2-chloroethyl)thio)-4-ethyl-5-(phenoxymethyl)-4H-1,2,4-triazole which demonstrates diuretic activity]. Biulleten, 9. [in Ukrainian]

[20] Kucheriavyi, Yu. M., Kaplaushenko, A. H., Pruglo, Ye. S. (patentee) (2015) Patent 98919 Ukraina, C07D 249/00, A61K 31/41. 4-etyl-3(fenoksymetyl)-5-((2-((5-(fenoksymetyl)-4-fenil-4H-1,2,4-triazol-3-il) tio)-etil)tio)-4H-1,2,4-triazol, scho vyiavliaie diuretychnu aktyvnist [Patent of Ukraine №98919. C07D 249/00, A61K 31/41. 4-ethyl-3-(phenoxymethyl)-5-((2-((5-(phenoxymethyl)-4-phenyl-4H-1,2,4-triazol-3-yl) thio)-ethyl)thio)-4H-1,2,4-triazole, which demonstrates diuretic activity] Biulleten, 9. [in Ukrainian]. 